\title{
OPEN Author Correction: Convergence and divergence of songs suggests ongoing, but annually variable, mixing of humpback whale populations throughout the North Pacific
}

\section{James D. Darling, Jo Marie V. Acebes, Oscar Frey, R. Jorge Urbán (i) \& Manami Yamaguchi}

Correction to: Scientific Reports https://doi.org/10.1038/s41598-019-42233-7, published online 07 May 2019

This Article contains a typographical error in the Introduction.

"Singing is largely but not exclusively seasonal, its occurrence increasing in fall feeding grounds, peaking during winter migrations and assembles, and decreasing in the spring ${ }^{3-8}$."

should read:

"Singing is largely but not exclusively seasonal, its occurrence increasing in fall feeding grounds, peaking during winter migrations and assemblies, and decreasing in the spring ${ }^{3-8}$ "”

In addition, this Article also contains an error in the Results section, under subheading 'Presence of phrases'.

"In 2013, the year of most similarity, four (Phrases 3, 4, 5, 6,) of a total of eight phrases (50\%) were shared in all four populations."

should read:

"In 2013, the year of most similarity, four (Phrases 3, 4a, 4c, 6) of a total of eight phrases (50\%) were shared in all four populations."

(c) (i) Open Access This article is licensed under a Creative Commons Attribution 4.0 International License, which permits use, sharing, adaptation, distribution and reproduction in any medium or format, as long as you give appropriate credit to the original author(s) and the source, provide a link to the Creative Commons license, and indicate if changes were made. The images or other third party material in this article are included in the article's Creative Commons license, unless indicated otherwise in a credit line to the material. If material is not included in the article's Creative Commons license and your intended use is not permitted by statutory regulation or exceeds the permitted use, you will need to obtain permission directly from the copyright holder. To view a copy of this license, visit http://creativecommons.org/licenses/by/4.0/.

(C) The Author(s) 2020 